\title{
Prevalence of mental disorders among sexual offenders and non-sexual offenders
}

\author{
Prevalência de transtornos mentais entre agressores sexuais e não sexuais \\ Maria Fernanda Faria Achá', Sérgio Paulo Rigonatti², Fabiana Saffi², Daniel Martins de Barros², \\ Antônio de Pádua Serafim²
}

\section{Keywords}

Epidemiology, violence, mental disorders, sex offenders.

\begin{abstract}
Objective: To evaluate the prevalence of mental disorders in convicted sex offenders admitted to the Psychiatric Custody and Treatment Hospital (Forensic Psychiatric Facility). Method: 89 patient records of males admitted from March 2005 to August 2006 were analyzed. The analysis included evaluation of two study groups: Group I comprised subjects who had committed sex offenses (sexual offenders) while Group II contained subjects convicted for other crimes (non-sexual offenders). Variables studied were: age bracket, years of schooling, marital status, skin color, place of birth, previous psychiatric admissions and psychiatric diagnosis. Results: Mental retardation and personality disorders were the mainly diagnoses in Group I (sexual offenders) (61,76\% and $29,41 \%$ respectively). In the other hand, schizophrenic subjects predominated in Group II (non-sexual offenders) (82,93\%). Conclusion: Different from international data, we have found low prevalence of personality disorders among Brazilian forensic population and we believe that it's due to a distinguishing characteristic of the Brazilian legal system, which does not consider personality disorder a mental disease, thus, not prompting these patients to civil commitment.
\end{abstract}

\section{RESUMO}

Objetivo: Avaliar a prevalência de transtornos mentais em pacientes em cumprimento de medida de segurança por crimes de natureza sexual e não sexual. Método: Foram analisados 89 prontuários de pacientes do sexo masculino internados no período de março de 2005 a agosto de 2006. A análise consistiu na avaliação de dois grupos de estudo assim divididos: Grupo I, composto de sujeitos que cometeram crimes sexuais, e Grupo II, formado por sujeitos que foram condenados por outros crimes que não de natureza sexual. As variáveis analisadas foram: idade, grau de escolaridade, estado civil, cútis, naturalidade, internações psiquiátricas anteriores e diagnóstico psiquiátrico. Resultados: Entre os sujeitos do Grupo I (condenados por crimes sexuais), observou-se maior prevalência de diagnóstico de retardo mental (61,76\%) e transtorno de personalidade (29,41\%). Já no Grupo II (condenados por crimes de outra natureza que não sexual), houve predominância do diagnóstico de esquizofrenia

\section{Palavras-chave}

Epidemiologia, violência, transtornos mentais, criminoso sexual. (82,93\%). Conclusão: Diferentemente do encontrado na literatura internacional, em nosso meio observou-se baixo índice de transtorno de personalidade entre os sujeitos estudados, o que pode ser justificado pelo fato de o sistema penal brasileiro considerar tal diagnóstico apenas como perturbação da saúde mental, não acarretando em medida de segurança ou internação psiquiátrica.

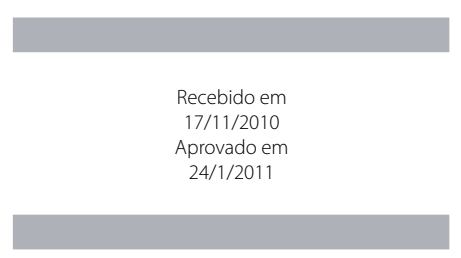

1 Universidade de São Paulo, Faculdade de Medicina (FMUSP), Programa de Psiquiatria. 2 USP, Departamento de Psiquiatria, Núcleo de Psiquiatria e Psicologia Forense. Instituição em que o trabalho foi elaborado: Hospital de Custódia e Tratamento Psiquiátrico Prof. André Teixeira Lima (HCTP).

Endereço para correspondência: Maria Fernanda Faria Achá

Rua Dr. Ovídio de Pires Campos, 785, Cerqueira César - 01060-970 - São Paulo, SP

Telefone: (11) 3069-7929

E-mail: mfernandaacha@usp.br 


\section{INTRODUCTION}

The motivations for human criminal behavior have been the subject of extensive study in several countries ${ }^{1-3}$. Although in its infancy, the field of forensic epidemiologic investigation has grown in importance, furthering our understanding of forensic phenomena ${ }^{4}$.

Gaining greater insight and knowledge on the risk or protective factors for violent behavior is valuable to guide intervention and prevention projects to reduce the incidence of crimes 5 . Surveys are devised to gain a better understanding of the etiology of violent behavior, and address clinical, epidemiological and etiological issues thought to be associated with violent behavior ${ }^{6}$. In fact, numerous studies have shown a highly complex association between mental diseases and violent behavior ${ }^{7-10}$. In some countries, the mentally ill who perpetrate crimes are incarcerated and treated in special institutions following their conviction. In Brazil, these entities are called "Casa de Custódia" (Custody Hospitals) and their remit is the isolation and treatment of the mentally ill'1".

Two studies carried out in Germany have highlighted the incidence of mental disorders among convicts ${ }^{2,7}$. The first of these studies investigated the prevalence of sexual offenders with axis I mental disorders and personality disorders, according to Diagnostic and Statistical Manual of Psychiatric Disorders (DSM-IV) criteria. The authors reported anxiety, mood, and drugs-related disorder as the most prominent axis I disturbances. With regard to personality disorders, the study identified anti-social personality, borderline and avoidant personality disorders as the most common diagnoses among the subjects studied?.

A study conducted in Germany ${ }^{2}$ compared the prevalence of mental disorders among sexual aggressors held at psychiatric institutions with that of sexual and non-sexual offenders. All three groups were found to share the diagnosis of substance use, a condition which had the highest incidence among all in-patients. Sexual aggressors admitted for psychiatric conditions presented a higher percentage of personality disorders and greater psychiatric comorbidity than did the other groups.

Another study, conducted in Iceland, investigated differences and similarities between violent offenders and two types of sex offender: rapists and child molesters. Results showed that violent offenders were more extroverted than the two groups of sex offenders and that child molesters tended to assault relatives and friends ${ }^{12}$.

Using the Mini International Neuropsychiatric Interview (MINI) on sex offenders in Germany, the authors ${ }^{13}$ found 39\% of subjects to have mood disorders, 30\% anxiety disorders, $19 \%$ anti-social personality disorders, $18 \%$ psychotic disorders, while 10\% had attention deficit disorder. Substance abuse was identified in $79 \%$ of subjects.
There is no consistent body of forensic studies available in Brazil. One study in the area by the São Paulo Casa de Custódia compiled data from the medical charts of institutionalized patients regarding criminal aspects, clinical profiles and profiles of victims. Based on the study population, a predominance of psychotic disorder was found, with $44 \%$ of subjects presenting comorbidity with the use of drugs. Homicide was found to be the most frequently committed crime and the most strongly associated with psychotic patients, while sexual crimes were associated with mentally retarded patients ${ }^{11}$.

Rigonatti et al. ${ }^{14}$ focused on the prevalence of personality disorder in criminals convicted for murder or rape who were serving sentences in a maximum security prison. The results pointed to a high incidence of personality disorder in both groups studied.

The aim of the present study was to compare the prevalence of mental disorders among sexual offenders and non-sexual offenders.

\section{METHODS}

The study was carried out at the Custody and Treatment Psychiatric Hospital "Prof. André Teixeira Lima" (formerly "Judiciary Asylum") located in the state of Sao Paulo. Medical records of patients admitted to hospital between March 2005 and August 2006 were randomly assessed. Of the 97 files selected, 18 were lacking relevant data and were therefore excluded from the sample, giving a total of 78 medical records. A draw was performed in order to form two groups: Group I comprised subjects who had committed sex offenses (sexual offenders) while Group II contained subjects convicted for other crimes (non-sexual offenders).

Information was collected from psychiatric and criminal records. Data on age, level of formal education, marital status, skin color, place of birth, previous psychiatric admissions and psychiatric diagnosis were obtained from the records. Only psychiatric reports produced by forensic psychiatrists from the institution were included in the analysis. The research project was approved by the ethic board of our institution ("Comissão de Ética para Análise de Projetos de Pesquisas CAPPesq da Diretoria Clínica do Hospital das Clínicas e da Faculdade de Medicina da Universidade de São Paulo - USP").

Data analysis included absolute and percentile frequency. The Chi-square test was used to compare groups for respective rates of specific diagnoses including other mental disorders secondary to brain damage or dysfunction, and due to physical disease, drug-related disorders, schizophrenia, mood disorders, mental retardation and epilepsy. In cases where the prerequisites for the chi-square test were not met, Fisher's exact test was employed. Significance level was $a=0.05$ for all comparisons. 


\section{RESULTS}

Table 1 depicts the demographics of both groups. The two groups analyzed showed no statistically significant differences. According the frequency of prior psychiatric admissions results showing that $76.7 \%$ of sexual offenders versus $86.1 \%$ of non-sexual offenders had prior psychiatric admissions ( $p=0.322)$. Comparison of specific diagnoses between sexual offenders and non-sexual offenders revealed a higher rate of schizophrenia (82.9\%) among non-sexual offenders $(p=0.000)$ and a higher prevalence of mental retardation among se-

Table 1. Demographic data of sexual offenders and non-sexual offenders

\begin{tabular}{lllll}
\hline \multicolumn{3}{l}{ Sexual offenders } & \multicolumn{2}{l}{ Non-sexual offenders } \\
\hline Age bracket & $\mathrm{N}=46$ & $\%$ & $\mathrm{~N}=43$ & $\%$ \\
$\mathrm{p}=0.003^{*}$ & & & & \\
$20-29$ & 09 & 19.57 & 05 & 11.6 \\
$30-39$ & 22 & 47.83 & 07 & 16.3 \\
$40-49$ & 12 & 26.09 & 23 & 53.5 \\
$50-59$ & 01 & 2.17 & 06 & 14 \\
$>60$ & 02 & 4.35 & 02 & 4.7 \\
\hline Marital status & & & & \\
$\mathrm{p}=0.046^{*}$ & & & & \\
Married & 10 & 22.2 & 03 & 7.3 \\
Divorced & 03 & 6.7 & 02 & 4.9 \\
Single & 32 & 71.1 & 36 & 87.8 \\
Missing** & 1 & & 2 & \\
\hline
\end{tabular}

Level of formal education

$p=0.013^{*}$

\begin{tabular}{lllll} 
Illiterate & 12 & 26.1 & 05 & 12.5 \\
Incomplete elementary & 29 & 63 & 27 & 67.5 \\
Elementary & 02 & 4.3 & 05 & 12.5 \\
Complete high school & 03 & 6.5 & 02 & 5.0 \\
College level & - & 0 & 01 & 2.5 \\
Missing & - & & 03 & \\
\hline
\end{tabular}

Skin color

$p=1.00^{*}$

\begin{tabular}{lllll} 
White & 28 & 60.9 & 27 & 62.79 \\
Black & 18 & 39.1 & 16 & 37.21 \\
\hline
\end{tabular}

Region of origin

$p=0.89^{*}$

North

Northeast

Central-West

Southeast

South

Missing**

*Chi-square test; *** Chi-square test did not consider missing values. xual offenders $(59.5 \%, p=0.000)$. All results from this variable analysis are shown in table 2.

Table 2. Comparison of specific diagnosis between sexual offenders and non-sexual offenders**

\begin{tabular}{|c|c|c|c|c|c|}
\hline \multirow[t]{2}{*}{ Pathology } & \multicolumn{2}{|c|}{$\begin{array}{c}\text { Sexual } \\
\text { offenders }\end{array}$} & \multicolumn{2}{|c|}{ Non-sexual offenders } & \multirow[t]{2}{*}{ p-value } \\
\hline & $\mathrm{N}$ & $\%$ & $\mathrm{~N}$ & $\%$ & \\
\hline $\begin{array}{l}\text { Mental disorders due } \\
\text { to brain damage and } \\
\text { dysfunction and to physical } \\
\text { disease }\end{array}$ & 3 & 8.82 & 1 & 2.44 & $0.323^{*}$ \\
\hline Drug-related disorders & 6 & 17.65 & 7 & 17.07 & 0.948 \\
\hline Schizophrenia & 11 & 32.35 & 34 & 82.93 & $<0.001$ \\
\hline $\begin{array}{l}\text { Mood } \\
\text { disorders }\end{array}$ & 1 & 2.94 & 0 & 0.00 & $0.453^{*}$ \\
\hline Personality disorders & 10 & 29.41 & 2 & 4.87 & 0.004 \\
\hline Mental retardation & 21 & 61.76 & 6 & 14.63 & $<0.001$ \\
\hline Epilepsy & 5 & 14.71 & 7 & 17.07 & 0.781 \\
\hline
\end{tabular}

\section{DISCUSSION}

Our socio-demographic data corroborate the findings in the national and international literature in terms of the prevalence of younger, single subjects and a low level of schooling among convicts. International studies in the forensic area are generally conducted in countries with a different reality to that of developing countries like Brazil, which have high rates of crime, alcohol or drugs use and school truancy. According to some authors, these features are risk factors for higher levels of violence ${ }^{5,15}$.

Cognitive performance proved another important variable. Mental retardation, for example, was the most prevalent diagnosis among the sexual offenders group. This disorder tends to evolve with educational difficulties. In Brazil, the natural history of the disorder, associated with the lack of specific programs catering to these patients' needs, hampers the social and professional adaptation of this patient group ${ }^{1,7}$.

A relationship between intelligence levels and crime has been proposed in a number of national and international papers ${ }^{1,16}$. The severity of the medical condition, degree of clinical support and social conditions are all potential factors underlying this relationship. According to researchers, subjects with less severe mental retardation are more likely to commit the type of crimes that require greater planning. On the other hand, individuals with more severe retardation tend to commit sex offenses or crimes that need less planning ${ }^{1,11}$.

In terms of psychopathology, though many studies have reported strong correlation between personality disorders and crime, this association requires broader and more in-depth studies in order to be relevant ${ }^{14,17,18}$. The role of schi- 
zophrenia, per example, in violent behavior is a point widely discussed in the forensic literature ${ }^{19,20}$. Some authors believe that psychotic symptoms such as delusion of persecution and auditory hallucinations, account for approximately $45 \%$ of cases of violence perpetrated by this patient group ${ }^{17-20}$. However, it's important to consider that many of these studies have found that the rate of violent behavior between schizophrenic patients is much higher among those who use some kind of toxic substance, such as alcohol and drugs ${ }^{19,20}$. It is also important to consider that this research could not be investigated among individuals who were part of the sample, which made use of psychoactive substance to the time of the offense. Cognitive impairment in atencional processes, executive functions, memory, learning and language are also considered to contribute to violent behavior in schizophrenics ${ }^{15,17,18}$.

There is also cause for concern over the application of specific laws in Brazil. Brazilians committing criminal acts are considered to be legally accountable, unaccountable, or partially (semi) accountable for their actions. The legal definition of accountable covers persons deemed capable of understanding the nature of their actions that are able to exercise self-control. By contrast, unaccountable individuals are those who, due to mental illness, incomplete mental development, mental retardation or other diseases, are unable to comprehend the full meaning of their actions or exert self-control. Finally, partially accountable individuals are those with mental disorders which at the time of the crime, could affect their self-control but do not alter the ability to understand their actions. Therefore individuals with personality disorders are frequently considered accountable or partially accountable, and thus enter the standard prison system as opposed to being placed into forensic custody and treatment facilities. The low prevalence of personality disorders among Brazilian forensic population compared to international rates is likely due to this distinguishing characteristic of the Brazilian legal system ${ }^{21-23}$.

The findings of this study are pertinent to all those who investigate the relationship between criminal behavior and mental disorders. Nevertheless, a methodological limitation of the study must be considered, like the lack of supplementary diagnostic instruments besides the clinical interview and patient history employed. The use of diagnostic instruments would have increased the reliability of the information used.

It is important to note that the present study in no way suggests that individuals with mental disorders are criminals. Our objective was to study and identify the patterns and prevalence of mental illness among civilly committed populations in order to better understand and treat this group.

\section{CONCLUSION}

This study sought to determine the prevalence of psychiatric diagnoses among subjects convicted of a range of crimes.
Socio-demographic profiles in both groups mirrored both national and international data. Regarding psychiatric diagnoses, a high prevalence of mental retardation and schizophrenia was found. The finding of low prevalence of personality disorders was an important discrepancy when compared our results with those of the international literature. This may be due to the nature of the Brazilian Penal Code, which determines that individuals with personality disorder enter the standard prison system.

Finally, we believe that the present study may encourage similar research in this area. Studies investigating the relationship between mental health and the justice system have attracted growing interest. This focus in countries like Brazil may stem from the increased level of urban violence which has prompted greater involvement of health professionals in investigating the etiological and epidemiological factors underlying violence. However, it should be emphasized that other lines of research such as bioethics, infanticide, personality disorders and infant-juvenile violence should also be incorporated in the scope of forensic research both in the Brazilian and International milieu.

\section{ACKNOWLEDGMENTS}

The authors extend their thanks to Carlos Tarifa Botta (Department Technical Director), Carlos Eduardo Garcia (Psychiatrist) and the whole team responsible for the records at the Psychiatric Custody and Treatment Hospital Prof. André Teixeira Lima (HCTP) in the city of Franco da Rocha - São Paulo State, for providing access to the study data.

\section{REFERENCES}

1. Fotiadou M, Livaditis M, Manou I, Kaniotou E, Xenitidis K. Prevalence of mental disorders and deliberate self-harm in Greek male prisoners. Int J Law Psychiatry. 2006;29(1):68-73.

2. Harsch S, Bergk JE, Steinert T, Keller F, Jockusch U. Prevalence of mental disorders among sexual offenders in forensic psychiatry and prison. Int J Law Psychiatry. 2006;29(5):443-9.

3. Barros P, Silva FBN. Origem e manutenção do comportamento agressivo na infância e adolescência. Rev Bras Ter Cogn. 2006;2(1):55-66.

4. Arboleda-Flórez J. Forensic psychiatry and epidemiology: Introduction. Int J Law Psychiatry. 2001;24(4-5):335-7.

5. Gallo AE, Williams LCA. Adolescentes em conflito com a lei: uma revisão dos fatores de risco para a conduta infracional. Psicologia: Teoria e prática. 2005;7(1):81-95.

6. Del Pino V, Werlang SG. Homicídio e lobo frontal: uma revisão da literatura. Interação em Psicologia. 2006;10(1):127-37.

7. Leue A, Borchard B, Hoyer J. Mental disorders in a forensic sample of sexual offenders. Eur Psychiatry. 2004;19(3):123-30.

8. Hodgins S, Mednick SA, Brenann PA, Schulsinger F, Engberg M. Mental disorder and crime: evidence from a Danish birth cohort. Arch Gen Psychiatry. 1996;53(6):489-96.

9. Mullen PE, Burgess P, Wallace C, Palmer S, Ruschena D. Community care and criminal offending in schizophrenia. Lancet. 2000;355(9204):614-7. 
10. Swanson JW, Holzer III CE, Ganju VK, Jono RT. Violence and psychiatric disorder in the community: evidence from the epidemiologic catchment area surveys. Hosp Community Psychiatry. 1990;41(7):761-70.

11. Teixeira EH, Dalgalarrondo P. Crime, diagnóstico psiquiátrico e perfil da vítima: um estudo com a população de uma casa de custódia do estado de São Paulo. J Bras Psiquiatr. 2006;55(3):192-4.

12. Gudjonsson GH, Sigurdsson JF. Differences and similarities between violent offenders and sex offenders. Child Abuse Negl. 2000;24(3):363-72.

13. Black DW, Arndt $S$, Hale N, Rogerson R. Use of the mini international neuropsychiatric interview (mini) as a screening tool in prisons: results of a preliminary study. I Am Acad Psychiatry Law. 2004;32(2):158-62.

14. Rigonatti SP, Pádua Serafim A, Freitas Caires MA, Filho AHGV, Arboleda-Florez J. Personality disorders in rapists and murderers from a maximum security prison in Brazil. Int J Law Psychiatry. 2006;29(5):361-9.

15. Valença AM, Moraes TM. Relação entre homicídio e transtornos mentais. Rev Bras Psiquiatr. 2006;28(II):S62-8
16. Coid J, Kahtan N, Gault S, Cook A, Jarman B. Medium secure forensic psychiatry services: comparison of seven English health regions. Br J Psychiatry. 2000;178(1):68-73.

17. Junginger J. Psychosis and violence: the case for a content analysis of psychotic experience. Schizophr Bull. 1996;22(1):91-103.

18. Monteiro LC, Louzã MR. Alterações cognitivas na esquizofrenia: consequências funcionais e abordagens terapêuticas. Rev Psiq Clín. 2007;34(2):179-83.

19. Elbongen EB, Johnson SC. The intricate link between violence and mental disorder. Arch Gen Psychiatry. 2009;66(2):152-61.

20. Fazel S, Långström N, Hjern A, Grann M, Lichtenstein P. Schizophrenia, substance abuse, and violent crime. J Am Med Assoc. 2009:301(19):2016-2.

21. Taborda JGV, Morana HCP, Cardoso RG. Forensic psychiatry in Brazil: an overview. Int J Law Psychiatry. 2000;23(5):579-88.

22. Trindade J. Manual de psicologia jurídica para operadores do direito. Porto Alegre: Livraria do Advogado; 2004.

23. Constituição da República Federativa do Brasil Diário Oficial da União; 1988. 